\title{
1.3 Проблема торгівлі людьми в умовах збройного конфлікту на території України
}

Одна 3 важливих світових проблем поліції та сучасного суспільства на сьогодні є пошук шляхів протидії та запобіганню торгівлі людьми. Це явище можемо назвати сучасною формою рабства і формою насильства, що спричиняє ризик для життя та здоров’я особи. Жодна країна світу не може цілком вберегти своїх громадян від цього тягаря, Україна не є винятком. Нестабільна соціальноекономічна ситуація, низький рівень правової культури населення, насильство проти жінок та дітей, корупція, політичний дисбаланс, конфлікт на сході України, безпринципність злочинців, нарощення попиту на дешеву робочу силу або неформальну працю, зростання потреб в сфері трансплантації органів створюють сприятливі умови для розвитку тіньового бізнесу у сфері торгівлі людьми. Актуальність проблеми торгівлі «живим товаром» в Україні, поглиблюється й тим фактором, що збройний конфлікт на сході став додатковим і сприяючим джерелом нарощення даного явища в нашій державі.

На сьогодні Україна є країною, з якої здійснюється експорт «живого товару» на світові «ринки» - до Туреччини, Італії, Польщі, Іспанії, Німеччини, Угорщини, Чехії, Греції, Об’єднаних Арабських Еміратів, Ізраїлю, Сполучених Штатів Америки та інших країн [23, с. 8].

Окуповані території, що знаходяться на сході України є чудовим фундаментом для процвітання свавільного беззаконня. Через непідконтрольність цих територій активно зростає кількість випадків торгівлі людьми. Збройний конфлікт на сході країни призвів до того, що люди, які там проживали, мусили змінювати місце життя, втрачати роботу, доходи, впевненість у завтрашньому дні, усе це зробило особливо вразливим їх для експлуатації.

Конвенція Організації Об'єднаних Націй проти транснаціональної організованої злочинності визначає торгівлю людьми як здійснювані 3 метою експлуатації вербування, перевезення, передачу, приховування або одержання людей шляхом загрози силою або іiі застосування або інших форм примусу, 
викрадення, шахрайства, обману, зловживання владою або уразливістю положення, або шляхом підкупу, у вигляді платежів або вигод, для одержання згоди особи, яка контролює іншу особу [24].

В українському законодавстві термін «торгівля людьми» подано у Законі України «Про протидію торгівлі людьми»: це здійснення незаконної угоди, об'єктом якої є людина, а так само вербування, переміщення, переховування, передача або одержання людини, вчинені з метою експлуатації, у тому числі сексуальної, з використанням обману, шахрайства, шантажу, уразливого стану людини або із застосуванням чи погрозою застосування насильства, 3 використанням службового становища або матеріальної чи іншої залежності від іншої особи» [25].

Законодавство у сфері боротьби 3 поширенням торгівлі людьми характеризується широким спектром не тільки національних законодавчих актів, але і міжнародними нормативно-правовими актами. А саме: Протокол про попередження i припинення торгівлі людьми, особливо жінками i дітьми, i покарання за неї; Конвенція Ради Свропи про заходи щодо протидії торгівлею людьми, Конвенція ООН про боротьбу з торгівлею людьми та експлуатацією проституції третіми особами, Закон України «Про протидію торгівлі людьми». Аналіз нормативно-правового поля протидії та запобігання торгівлі людьми, показує, що не дивлячись на те, що антитерористична операція на території Донецької та Луганської областей проводиться вже не один рік, засоби боротьби 3 явищем продажу «живого товару» залишилися і по сьогодні такими як і в мирний час.

Сфера торгівлі людьми в тіньовому секторі економіки здійснюється з метою трудової й сексуальної експлуатації, а також для використання в жебрацтві, порнобізнесі, збройних конфліктах, втягнення у злочинну діяльність, вилучення органів, проведення дослідів над людиною без її згоди та інше.

Збройний конфлікт дає можливості не лише для протизаконного переміщення зброї, боєприпасів, наркотиків, але й людей. Нова для України група ризику, що може легко стати жертвою тіньового ринку є вимушені 
переселенці або внутрішньо переміщені особи із зони збройного конфлікту на Сході України. Основними причинами поширення торгівлі людьми є такі фактори: нестатки; привабливість кращих умов життя в іншому місці; неможливість працевлаштування; організована злочинність; дискримінація жінок; насильство над жінками; політична нестабільність; збройні конфлікти; попит на послуги в секс-індустрії; важке економічне становище громадян і безробіття [26, с. 28-29]. Перераховані чинники мають позитивний вплив на поширення торгівлі «живим товаром».

Через невизначеність перспектив щодо подальшого розміщення та працевлаштування, побутові труднощі та брак ресурсів (зокрема, фінансових), вимушені переселенці або внутрішньо переміщені особи із зони збройного конфлікту $є$ особливо вразливими та схильними до прийняття сумнівних пропозицій вербувальників. Значна кількість переселенців намагаються отримати притулок чи роботу за кордоном, а брак знань міжнародного та внутрішнього законодавства інших країн відносно статусу біженця чи шукача притулку сприяє стати обманутим шахраями чи торгівцями людьми. Саме тому, 3 метою недопущення торгівлі «живим товаром» та протидії цього явища, на окупованих територіях Сходу України необхідно:

- посилити взаємодію оперативних підрозділів Національної поліції та військовослужбовців, що несуть службу в зоні Операції об’єднаних сил на пунктах пропуску;

- постійно проводити роз'яснювальну роботу у цьому напряму військовослужбовцями та волонтерами, що знаходяться у зоні Операції об’єднаних сил, серед населення;

- поглибити механізм проведення спільних заходів оперативних та слідчих підрозділів поліції у виявленні, документуванні та розслідуванні кримінальних правопорушень цієї категорії справ.

Однією з найнебезпечніший та найстрашніших форм торгівлі людьми, на нашу думку, є торгівля людьми з метою вилучення у них органів або тканин для трансплантації. «Чорний ринок людських органів», на жаль, активно 
розвивається в Україні. Найчастіше саме громадяни нашої країни стають жертвами «чорних трансплантологів» на світовому ринку. Збройний конфлікт діє як каталізатор для збільшення правопорушень в цьому аспекті.

На сьогодні в Україні, є ознаки, які вказують на розширення «чорного» ринку органів і тканин людини. Недоліки у законодавстві, яким регулюється пересадка органів, і пов'язані з цим комерційні інтереси, корупція і шахрайство створюють підгрунтя для розвитку незаконної торгівлі органами людини. Такі злочини вже вийшли за межі національних, тому боротьба 3 ними вимагає скоординованих зусиль світової спільноти [27, с. 10]. «Чорна трансплантологія» $\epsilon$ глобальною міжнародною проблемою. Найстрашніше те, що через це явище гинуть ні в чому не винні люди, а частіше за все і діти. Про це свідчать неодноразові зникнення дітей з невідомою їх подальшою долею. Або коли їх знаходили вже мертвими без деяких життєво необхідних органів.

Незаконне вилучення у потерпілого органів чи тканин для трансплантації означає примушування потерпілого до вилучення у нього органів, тканин, а також крові людини чи іiі компонентів шляхом застосування фізичного чи психічного насильства, погроз, обману, з використанням безпорадного стану чи його залежність від винного. Отримання згоди потерпілого на вилучення у нього органів, тканин, крові все одно утворює склад злочину передбаченого ст. 149 Кримінального кодексу України. Незважаючи на те, що люди нібито добровільно погоджуються на вилучення органів, відповідно до законодавства України отримання згоди потерпілого на вилучення у нього органів, тканин, крові все одно утворює склад злочину ст. 149.

Для вилучення у людини органів чи тканин шляхом примушування або обману, характерним є вчинення їх організованими злочинними групами, до складу яких можуть входити медичні працівники (лікарі швидкої медичної допомоги, анестезіологи-реаніматологи, хірурги, операційні сестри, судовомедичні експерти та ін.), а також особи, які не входять до числа медичних працівників, та належать до кримінальних структур, що спеціалізуються на вчиненні таких злочинів [27, с. 10]. 
Злочини у сфері трансплантації органів або тканин людини характеризуються певними негативними факторами, а саме: наявністю «тіньових» схем роботи медичних установ, відсутністю всеукраїнського банку органів і тканин, загальнодоступності медичної допомоги, недостатньою кількістю клінік з пересадки органів, недостатнім рівнем розвитку вітчизняних клінік з трансплантації органів, недоліками у діяльності медичних установ, неправильним уявленням у суспільстві про донорство, недостатнім розвитком у суспільстві принципів гуманізму, а також практики добровільних пожертвувань, відсутністю системи заохочення фізичних осіб за добровільне пожертвування органів, існуванням «трансплантаційного туризму» (продаж органів і тканин при виїзді за кордон), наявністю «чорного ринку» людських органів і тканин, корупцією медичних працівників, скрутним матеріальним становищем осіб, які пропонують власні органи на продаж, чутками про викрадання людей з метою продажу їх органів, крадіжками органів хірургами під час планових операцій, відсутністю належної роз'яснювальної роботи медичних установ про правильне донорство (пожертвування органів), недостатнім контролем за діяльністю медичних установ з боку громадських організацій, можливістю заробити на продажі своїх органів, недостатньо суворими санкціями кримінального закону за здійснення незаконної трансплантації органів тощо [27, с. 11]. На сьогодні через тимчасово окуповану територію йде активне переміщення жертв торгівлі людьми, оскільки «торгівлею людьми вважається злочин, що був учинений як при перетині державного кордону, так і без цього, що не є його визначальною ознакою» $[23$, с. 5$]$.

Проте потрібно звернути увагу на те, що в межах країни набагато легше знайти особу, ніж за ії межами. Вважаємо за необхідне розмежування торгівлі людьми в межах країни та торгівлі людьми з перетином державного кордону. Таке розмежування повинне передбачати різне покарання у санкції статті Кримінального кодексу.

За торгівлю людьми передбачена кримінальна відповідальність за статтею 149 Кримінального кодексу України, в якій указується: «Торгівля людиною, а 
так само вербування, переміщення, переховування, передача або одержання людини, вчинені з метою експлуатації, з використанням примусу, викрадення, обману, шантажу, матеріальної чи іншої залежності потерпілого, його уразливого стану або підкупу третьої особи, яка контролює потерпілого, для отримання згоди на його експлуатацію» [28]. Звернувши увагу на санкцію ст. 149, що передбачає кримінальну відповідальність від 3 до 8 років позбавлення волі, маємо сказати, що для такого виду злочину таке покарання є досить гуманним. Вважаємо, що термін кримінального покарання за торгівлю людьми має бути значно вищим. Насамперед це пов’язано з тим, що цей злочин руйнує людську гідність, життя, стає причиною психологічної травми, не всі люди здатні відновитися після пережитого, не усіх жертв є можливість у поліції знайти за кордоном та повернути додому.

Отже, поширення торгівлі людьми через непідконтрольний схід України є глобальною проблемою, що потребує негайного вирішення. Військовий конфлікт породжує грубі порушення прав і свобод людини, зокрема сприяє й торгівлі людьми. Українська влада повинна вберегти своїх громадян від цих злочинів i встановити таке покарання за цей злочин, яке буде суттєвим i справедливим. На законодавчому рівні необхідно прийняти зміни, що значно посилять юридичну відповідальність за статтями Кримінального кодексу відносно торгівлі «живим товаром» (секс-торгівлі, рабства, безоплатної трудової експлуатації, незаконне переміщення дітей за кордон), а також окремо вважаємо слід внести статтю в цей кодекс із суттєвими санкціями щодо «чорної трансплантології» та «трансплантаційного туризму». Цілком логічно, що потребують змін і нормативно-правові акти відносно протидії та запобіганню торгівлі людьми уповноваженими органами Національної поліції в яких би віддзеркалювалися особливості проведення таких заходів на тимчасово окупованій території. 